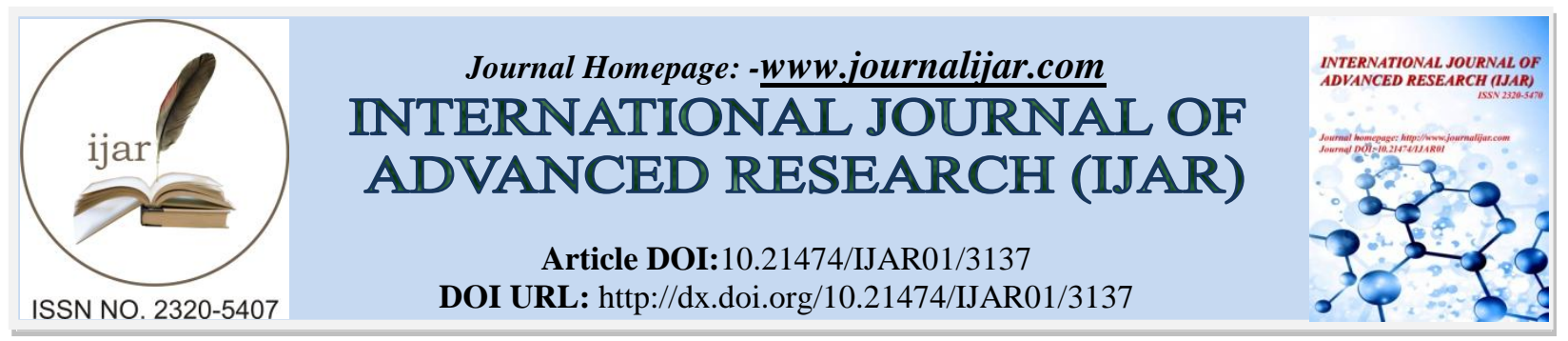

RESEARCH ARTICLE

\title{
CONSERVATION OF BIODIVERSITY WITH PARTICULAR REFRENCE OF BUTTERFLY FAUNA OF GIR PROTECTED AREA, GUJART.
}

Anchal Sharma, Dr. S. I. Ahmed and Dr. Sandeep Kumar.

\section{Manuscript Info}

Manuscript History

Received: 12 December 2016

Final Accepted: 15 January 2017

Published: February 2017

Key words:-

Gir National Park, Indian Wildlife

(Protection) Act 1972,Pollard walk,

Species diversity.

\section{Abstract}

A detailed study on the butterfly species diversity was carried out during 2011 and 2014 using Pollard walk method in the Dry Deciduous Teak forest of GirNational Park in Junagadh District of Gujarat State, India to assess theprotected species undervarious schedules of the Wildlife (Protection) Act, 1972.

\section{Introduction:-}

India with only $2.3 \%$ of the total land mass has around 91,206 animal species comprising $7.43 \%$ of the total (Ramakrishna and Alfred, 2007). Taking cognizance of the alarming situation of the depletion of natural habitats, the Government of India took significant steps in establishing the Indian Board for Wildlife in 1952 followed by the Indian Wildlife (Protection) Act, 1972. India also became signatory to the CITES, IUCN and world-wide Fund for nature. The Government of India has so far protected more than 4\% of the geographical area, with 99 National Parks, 513 Wildlife Sanctuaries, 41 Conservation Reserves and 4 Community reserves (Anonymous, 2008) with a forest cover of $20.64 \%$ (Anonymous, 2003).

The Government of India under Indian Wildlife (Protection) Act, 1972 provided protection to 452 species of butterfly in three Schedules (out of six) as in Schedule I, Part IV, 128 species of butterfly; in Schedule II, Part II, 305 species and in Schedule IV (Secs. 2,8,9,11 and 61), 19 species (Anonymous, 2003). Due to advancement in taxonomy, the names of species and their families changed.Sharma and Ramamurthy (2010) have updated the list of 452butterfly species and their families as per Indian Wildlife (Protection) Act, 1972 updated.The export of butterflies (dead or alive) and decorative articles from them are prohibited. As per Section-40 (92) of the Act, no person can acquire, receive, to keep in control, custody or possession, any of the species included in the above schedule without previous permission in writing of the Chief Wildlife Warden or his authorized officer.

The available information on the conservation importance of Indian butterfly's species and sub- species is very meagre. Though, some earlier authors (Sharma and Ramamurthy, 2010 and Kunte, 2008) have published various accounts on the insects, to be included in the WPA, 1972. During the Couse of the present investigation, an attempt has been made to assess the protected species of butterflies of Gir National Park under various schedules of the Wildlife (Protection) Act, 1972.

\section{Material and Methods:-}

The survey was conducted during 2011-2014 using Pollard Walk on fixed transects as per the methodology adopted by Pollard and Yates(1993) in order to enumerate the butterfly species in ten different habitats of Gir PAs. Existing 
patrolling paths were used as transects for surveys. All flying butterflies on these selected transects were recorded between 9.00 am to $4.00 \mathrm{pm}$.

For the purpose of collection of samples, a data sheet was designed following the techniques developed and adopted by Pollard and Yates, (1993) which is comprised withall the variables such as abiotic factors, GPS factors, host plants etc.(separately), collected from each of the study - sites in Gir PA Gujarat.

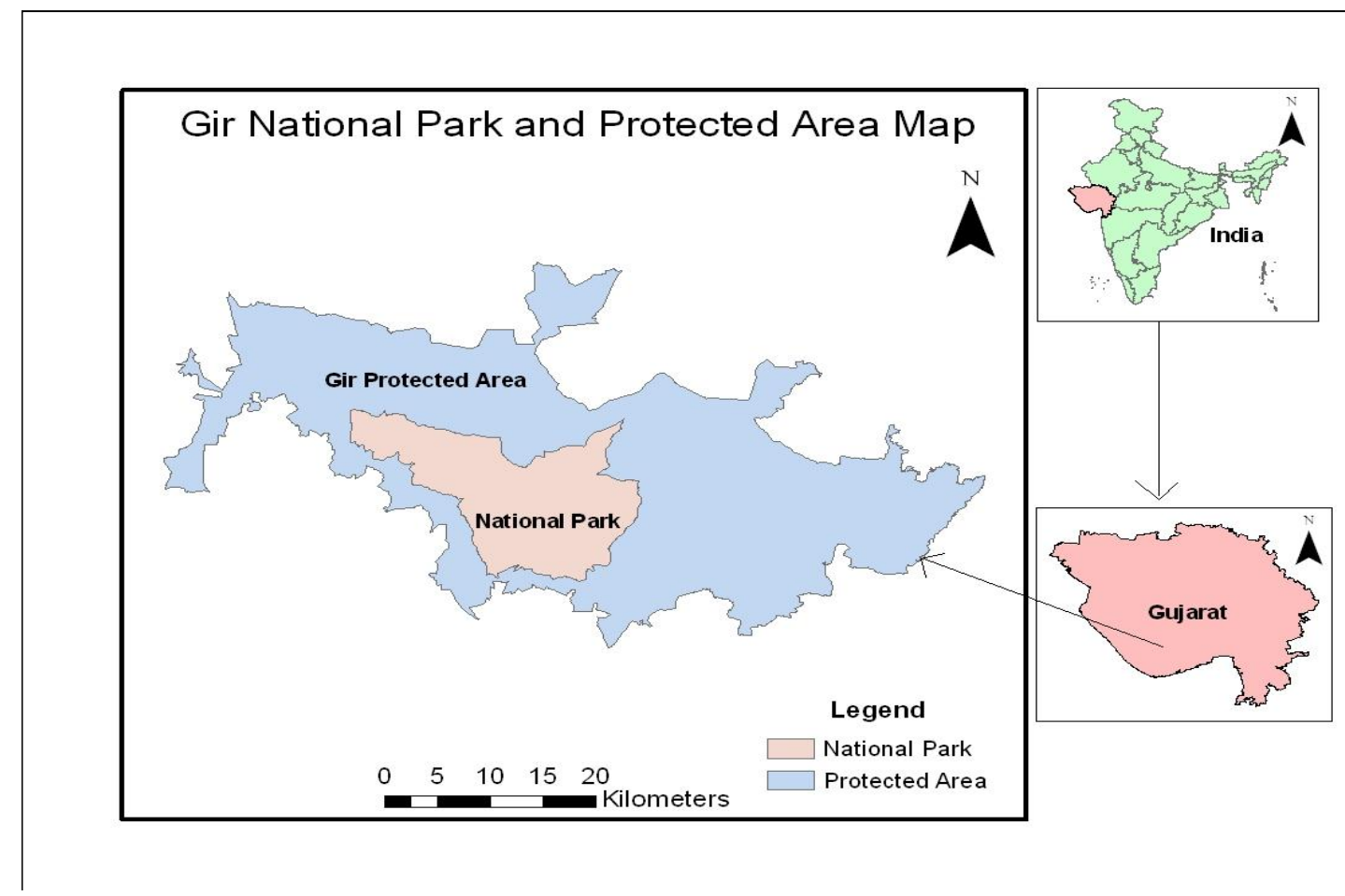

\section{Results and Discussion:-}

A total of 67 species belonging to all 42 genera, representing 4 families, have been recorded from GPA. The family Nymphalidae was found dominant with 15 genera and 23 species followed by family Pieridae representing 10 genera and 22 species. Family Lycinidae is comprised of 14 genera and 16 species whereas Papilionidae with 3 genera and 6 species.

Table 1:- Distribution of butterfly species family- wise in GPA

\begin{tabular}{|l|l|l|l|l|}
\hline S.No. & Family & Common Names & Genera & Species \\
\hline 1. & Pailionidae & Swallowtail butterflies & 3 & 6 \\
\hline 2. & Pieridae & White and yellow butterflies & 10 & 22 \\
\hline 3. & Nymphalidae & Brush-footed butterflies & 15 & 23 \\
\hline 4. & Lycaenidae & $\begin{array}{l}\text { Blues, hairstreaks \& gossamer- } \\
\text { winged butterflies }\end{array}$ & 14 & 16 \\
\hline & Total & $\mathbf{4 2}$ & $\mathbf{6 7}$ \\
\hline
\end{tabular}

The existing check- list containing 44 species of butterfly as presented by Kiran and Ahir (2005)from GPA has been updated to 67 species, thus 23 species has been added to the earlier recorded checklist which was comprised of only 44 species. 


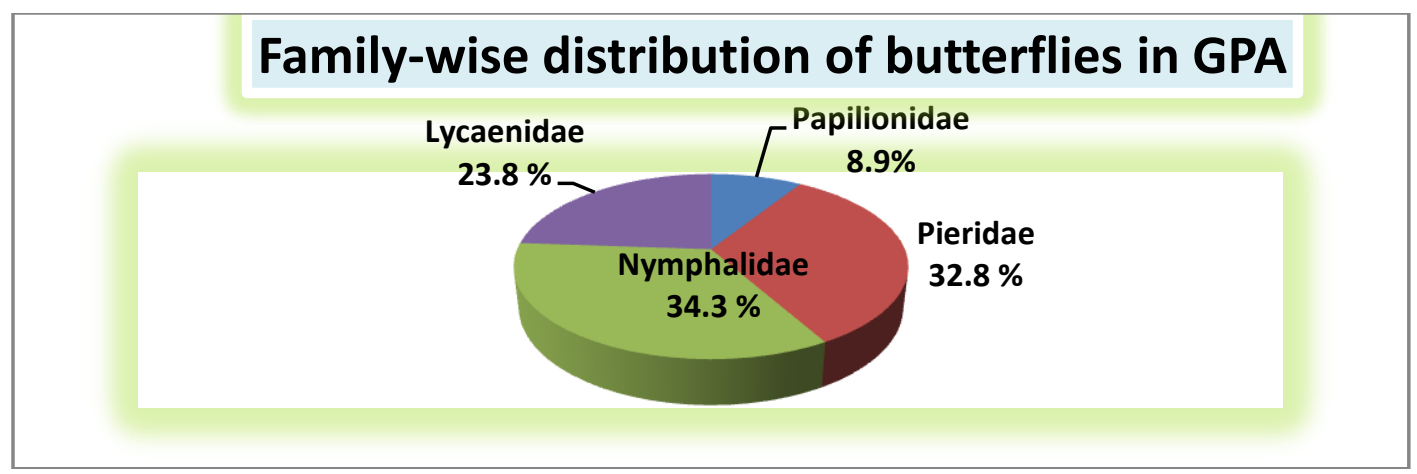

Among the 67 species recorded from GPA during the study of two years, four species of butterflies Pachiliopta hector, Hypolimnasmissipus, Castaliusrosimonand Dendoryxepijarbasare included Schedule -I and another four species namely Charaxesfabius, Ceporanerissa, EuchrysopscnejusandLampidesboeticusare included under Schedule -II, while remaining only one species Euploea corecomes under Schedule - IV as per Wildlife protection Act (1972).

Table 2:- List of butterflies with their status (Wild Life Protection Act- 1972) in GPA.

\begin{tabular}{|c|c|c|c|}
\hline S.No & Family & Species & Status as WPA (1972) \\
\hline 1. & Papilionidae & Pachiliopta hector & Schedule - 1 (WPA- 1972) \\
\hline 2. & Nymphalidae & Hypolimnasmissipus & Schedule - I (WPA- 1972) \\
\hline 3. & Nymphalidae & Charaxesfabius & Schedule - II (WPA- 1972) \\
\hline 4. & Nymphalidae & Ceporanerissa & Schedule - II (WPA- 1972) \\
\hline 5. & Nymphalidae & Euploea core & Schedule - IV (WPA- 1972) \\
\hline 6. & Lycaenidae & Euchrysopscnejus & Schedule - II (WPA- 1972) \\
\hline 7. & Lycaenidae & Castaliusrosimon & Schedule - I (WPA- 1972) \\
\hline 8. & Lycaenidae & Lampidesboeticus & Schedule - II (WPA- 1972) \\
\hline 9. & Lycaenidae & Dendoryxepijarbas & Schedule - I (WPA- 1972) \\
\hline
\end{tabular}

While sampling in the GPA, eight species of butterflies e.g., Graphiumnomius, Ariadne merione, Bybliailithiya, Parenoniavaleria, Tarucustherophrastus, Azanusjeasons, andSpindasisictiswere rarely encountered in a very less numbers and as such these species have been given a status of rare species in respect of GPA.

Table 3:- Status of rare - species in GPA as per the revised and updated check-list of GPA

\begin{tabular}{|c|c|c|c|}
\hline S.No & Family & Species & Status in GPA \\
\hline 1. & Papilionidae & Graphiumnomius & Rare \\
\hline 2. & Nymphalidae & Ariadne merione & Rare \\
\hline 3. & Nymphalidae & Bybliailithiya & Rare \\
\hline 4. & Pieridae & Parenoniavaleria & Rare \\
\hline 5. & Lycaenidae & Curetisthetis & Rare \\
\hline 6. & Lycaenidae & Tarucustherophrastus & Rare \\
\hline 7. & Lycaenidae & Azanusjeasons & Rare \\
\hline 8. & Lycaenidae & Spindasisictis & \\
\hline
\end{tabular}




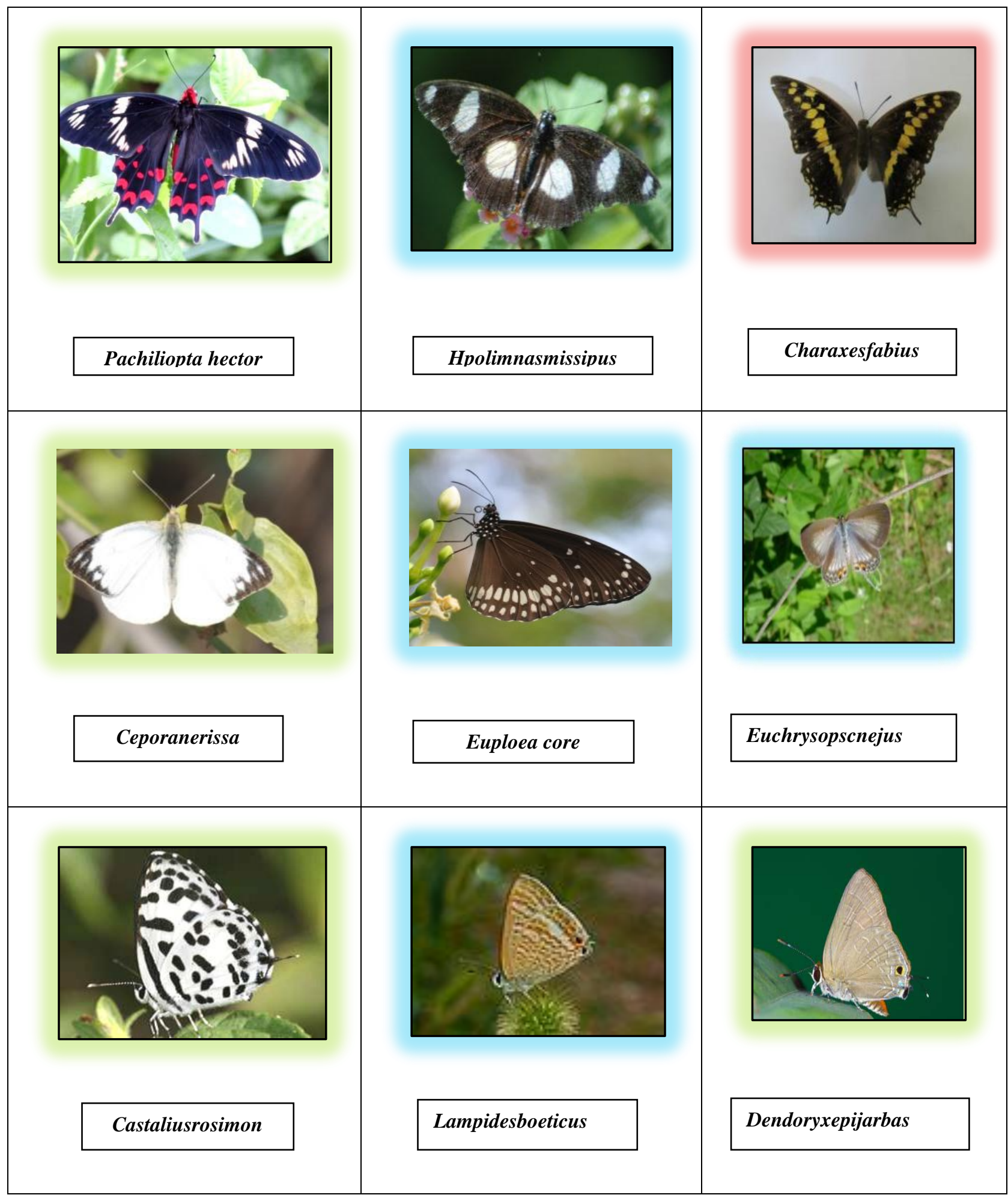

Fig:- Speciesof butterflies protected underWild Life Protection Act- 1972 in GPA.

\section{Acknowledgements:-}

This study was part of Ph. D research work, AFRI, Jodhpur (FRI - Dehradun). The author is thankful to Director AFRI, CCF and DCF Gir National Park, for providing the necessary facilities to carry out this study and Department of Science and Technology (DST), New Delhi for funding. 


\section{Refrences:-}

1. Anonymous.(2003). State of Forest Report-2003. Forest Survey of India (Ministry of Environment and Forests), Dehra Dun. 184.

2. Anonymous.(2008). Annual Report-2007-2008-Part-1.Ministry of Environment and Forests, Government of India, New Delhi. 79.

3. Current Science. 94(6): 729-735.

4. Kunte, K. (2008). The Wildlife (Protection) Act and conservation prioritization of butterflies of the Western Ghats, South Western India.

5. Pollard, E. and Yates, T. J. (1993). Monitoring butterflies for ecology and conservation. Chapman and Hall, London.

6. Ramakrishnaand Alfred, J.R.B. (2007). Faunal Resources in India.Published by the Director, Zool. Surv. India, Kolkata. 1-427.

7. Sharma, G. and Ramamurthy, V. V. (2010). Status of Butterflies, their protection under Indian Wildlife (Protection) Act, 1972 and their conservation in India. In: Advancement in Invertebrate Taxonomy and Biodiversity (Ed. Gupta, R.) 560pp. Published by Agrobios (International), Jodhpur. 349-372. 